\title{
FAKTOR-FAKTOR YANG BERPENGARUH TERHADAP INTENSI BERWIRAUSAHA MAHASISWA UNIVERSITAS TARUMANAGARA
}

\author{
Elysaberth $^{1}$, Kartika Nuringsih ${ }^{2}$ \\ ${ }^{1}$ Program Studi Manajemen, Fakultas Ekonomi dan Bisnis, Universitas Tarumanagara \\ Email: elysaberth.115170359@stu.untar.ac.id \\ ${ }^{2}$ Program Studi Manajemen, Fakultas Ekonomi dan Bisnis, Universitas Tarumanagara* \\ Email: kartikan@fe.untar.ac.id \\ *Penulis Korespondensi
}

Masuk : 04-02-2021, revisi: 10-02-2021, diterima untuk diterbitkan :02-03-2021

\begin{abstract}
ABSTRAK
Penelitian ini bertujuan untuk: 1) menguji pengaruh pendidikan kewirausahaan terhadap intensi berwirausaha siswa 2) menguji pengaruh sikap terhadap intensi berwirausaha siswa 3) menguji pengaruh latar belakang keluarga terhadap intensi berwirausaha siswa. Sampel dalam penelitian ini adalah 100 mahasiswa Universitas Tarumanagara, Fakultas Ekonomi dan Bisnis. Teknik pengambilan sampel yang digunakan adalah purposive sampling. Teknik pengumpulan data yang digunakan adalah kuisioner online melalui google form. Hasil penelitian menunjukkan bahwa 1) pendidikan kewirausahaan mempengaruhi intensi berwirausaha siswa, 2) sikap mempengaruhi intensi berwirausaha siswa, 3) latar belakang keluarga mempengaruhi intensi berwirausaha siswa.
\end{abstract}

Kata Kunci: Pendidikan, Sikap, Keluarga, Intensi Berwirausaha

\section{ABSTRACT}

This study aimed to: 1) examine the effect of entrepreneurship education, towards student's entrepreneurial intention 2) examine the effect of attitude, towards student's entrepreneurial intention 3) examine the effect of family background, towards student's entrepreneurial intention The sample in this study were 100 students of Tarumanagara University, Faculty of Economy and Business. The sampling technique used is purposive sampling. Data collection technique used is online questionnaire through google form. The findings show that 1) entrepreneurship education affect student's entrepreneurial intention, 2) attitude affect student's entrepreneurial intention 3) family background affect student's entrepreneurial intention.

Keywords: Education, Attitude, Family, Enterpreneurial Intention

\section{PENDAHULUAN}

\section{Latar Belakang}

Akar permasalahan dari tingginya angka pengangguran ditingkat pendidikan tinggi ini antara lain adalah paradigma berpikir lulusan yang masih berorientasi pada jobseeker (Endah, 2013). Selain itu, dampak lain dari krisis tersebut telah menciptakan isu untuk bisnis menjadi kurang efisien (Sivarajah \& Achchuthan, 2013). Salah satu solusi mengatasi pengangguran dengan memberikan bekal ketrampilan serta menumbuhkan jiwa kewirausahaan (Sukidjo, 2005). Oleh karena itu, jumlah wirausaha di Indonesia harus ditingkatkan.

Pendidikan merupakan solusi yang tepat untuk mengurangi masalah pengangguran, karena dengan pendidikan yang baik akan melahirkan sumber daya manusia yang baik, tetapi dengan jumlah penduduk yang banyak, mengakibatkan susasana kerja yang kompetitif, mengakibatkan pengangguran terdidik. "Pendidikan entrepreneurship dipandang sebagai salah satu faktor penentu dalam upaya meningkatkan sikap entrepreneurial seseorang” (Chairy, 2011). 
Menurut Wilson et al. (2007) pendidikan kewirausahaan merupakan suatu dukungan untuk membantu siswa dalam mengekspresikan niat lebih lanjut untuk memulai usaha mereka sendiri, meningkatkan keinginan dan menginspirasi mereka untuk mengambil tantangan baru. Salah satu penelitian yang dijalankan oleh Yasir et al. (2018) yang berjudul "Entrepreneurial self-efficacy and intention: do entrepreneurial creativity and education matter?" memiliki sampel yaitu mahasiswa di universitas di China dan Spain. Penelitian ini memiliki hasil yaitu EE (entrepreneurial education) memiliki hubungan yang positif dan signifikan terhadap EI (entrepreneurial intention).

Sikap juga berpengaruh dalam menumbuhkan jiwa berwirausaha karena agar mampu mengidentifikasi peluang usaha, kemudian mendayagunakan peluang usaha untuk menciptakan peluang kerja baru. Menurut Susita (2013) Sikap kewirausahaan adalah suatu pernyataan proporsional seseorang terhadap cara mengenali, cara pandang, perasaan dan kecenderungan melakukan sesuatu dalam lingkup aspek pelayanan ke pelaku usaha, dengan ciri-ciri berpikir inovatif, berpikir fleksibel, teguh pada pendirian, percaya diri, mempengaruhi orang lain, suka tantangan, tanggap terhadap perubahan, pengambilan keputusan, dan memanfaatkan peluang.

Keluarga merupakan sumber dukungan yang sangat penting bagi satu individu untuk memulai kegiatan kewirausahaan. Oleh karena itu, hal ini adalah nilai teoritis dan perlu untuk mempertimbangkan lingkungan keluarga seseorang sebagai prediktor kemampuan kewirausahaannya. Keluarga secara umum diakui sebagai salah satu sumber daya penting yang menyemangati karyawan, sedangkan konflik pekerjaan-keluarga berdampak negatif atau bahkan menghancurkan kinerja pekerjaan mereka (Michel et al., 2011).

Berdasarkan latar belakang yang telah diuraikan, maka permasalahan yang peneliti dapat uraikan adalah kurangnya lapangan pekerjaan yang ada di Indonesia yang menyebabkan pengangguran karena kurangnya minat mahasiswa untuk berwirausaha. Juga kurangnya pendidikan kewirausahaan akan membuat mahasiswa tidak memiliki pengetahuan yang cukup untuk dapat memiliki keinginan berwirausaha. Mahasiswa yang kurang menyadari akan sikap kewirausahaan akan kesulitan untuk mengidentifikasi peluang usaha dan menghambat intensi berwirausaha. Latar belakang keluarga yang tidak mendukung akan membuat mahasiswa tidak mendapatkan dukungan yang bersifat material atau moral sehingga akan menghambat intensi berwirausaha. Adapun tujuan penelitian yang dilakukan oleh peneliti berkaitan dengan masalah yang telah diuraikan adalah untuk mengetahui dan menganalisis pengaruh pendidikan kewirausahaan terhadap intensi berwirausaha, mengetahui dan menganalisis pengaruh sikap terhadap intensi berwirausaha, dan mengetahui dan menganalisis pengaruh latar belakang keluarga terhadap intensi berwirausaha.

\section{Kajian teori}

Dalam beberapa literatur, dijelaskan bahwa pengetahuan dan keterampilan kewirausahaan dapat diajarkan dan dikembangkan dengan menyediakan lingkungan yang sesuai dan bahwa pendidikan memainkan peran penting dalam proses pembangunan kapasitas kewirausahaan (Hannon, 2006). Menurut Mwoma dan Pillay, (2016) dukungan pendidikan adalah serangkaian inisiatif yang dirancang untuk meningkatkan pembangunan ekonomi nasional melalui investasi konstan dalam pendidikan berkualitas yang didukung oleh sejumlah guru yang memadai dan alat pembelajaran yang relevan.

Tujuan utama pendidikan kewirausahaan adalah mengembangkan pengetahuan dan prosedur yang diperlukan untuk membangun dan menumbuhkan perusahaan yang sukses. Ada ada tiga 
tujuan utama untuk pendidikan kewirausahaan yang efektif, pertama, yaitu mengembangkan pemahaman yang luas tentang kewirausahaan, kedua memperoleh pola pikir kewirausahaan dan yang ketiga adalah serta bagaimana memulai dan menjalankan usaha secara efektif (Gibb, 2005).

Menurut Cruz et al. (2015), sikap merupakan kecenderungan untuk bereaksi secara efektif dalam menanggapi risiko yang ada di depan dalam suatu bisnis. Perilaku merupakan kesiapan bereaksi terhadap objek tertentu di lingkungan sebagai apresiasi terhadap objek tersebut. Sikap reaksi individu terhadap suatu objek di lingkungan, dalam penelitian ini objek tersebut adalah kewirausahaan. niat. Indikator sikap terhadap niat berwirausaha dilihat dari minat individu dengan peluang usaha, pandangan positif terhadap kegagalan usaha, dan kepentingan bisnis yang berisiko.

Keluarga merupakan sumber dukungan yang sangat penting bagi satu individu (Zachary, 2011), termasuk memulai kegiatan kewirausahaan. Oleh karena itu, ini adalah nilai teoritis dan perlu untuk mempertimbangkan lingkungan keluarga seseorang sebagai prediktor kemampuan kewirausahaannya. Keluarga secara umum diakui sebagai salah satu sumber daya penting yang menyemangati karyawan, sedangkan konflik pekerjaan-keluarga berdampak negatif atau bahkan menghancurkan kinerja pekerjaan mereka (Michel et al., 2011).

Latar belakang keluarga menurut Honig dan Davidsson (2000) dan Baughn et al. (2006) bisa didefinisikan dalam bentuk dukungan emosional dan / atau akses ke modal dari teman dan keluarga atau sumber material dan non material. Misalnya, jika seorang siswa tahu bahwa ia memiliki dukungan kuat dari orang tua dan anggota keluarga mereka baik material maupun non material, dan juga memiliki akses ke informasi bisnis, kesediaan mereka untuk menjelajah ke dalam bisnis baru akan cenderung ditingkatkan, sehingga meningkatkan kepercayaan diri mereka dan mendorong minat mereka untuk berwirausaha (Ismail et al., 2009).

\section{Hubungan antara Variabel}

Menurut Mwoma dan Pillay (2016) dukungan pendidikan adalah serangkaian inisiatif yang dirancang untuk meningkatkan pembangunan ekonomi nasional melalui investasi konstan dalam pendidikan berkualitas yang didukung oleh sejumlah guru yang memadai dan alat pembelajaran yang relevan.

Keyakinan untuk meraih sukses harus diimbangi sikap yang selalu ingin tahu, dengan sikap ini, individu akan memiliki minat untuk belajar dan meningkatkan diri. Tanpa sikap ini, keyakinan hanya akan tetap sebagai keyakinan fiksi. Oleh karena itu, kita harus membangun sikap jiwa diri yang kuat agar kita dapat memberanikan diri untuk memulai suatu usaha (Indarti, 2020).

Seorang individu yang berkaitan dengan suatu kewirausahaan atau tidak, pasti membutuhkan dukungan dari orang lain, terutama relasi terdekatnya seperti teman atau keluarga. Dukungan relasi menurut Baughn et al. (2006) yaitu bisa dalam bentuk dukungan emosional dan atau akses ke modal dari teman dan keluarga.

\section{Penelitian yang Relevan}

Salah satu penelitian yang berjudul "Entrepreneurial self-efficacy and intention: do entrepreneurial creativity and education matter?" memiliki sampel yaitu mahasiswa di universitas di China dan Spain. Penelitian ini menggunakan metode kuesioner yang memiliki 387 valid kuesioner dari China dan 421 valid kuesioner dari Spain. Tujuan dari penelitian ini adalah untuk mentukan hubungan antara ESE terhadap EI yang dimediasi oleh EC, EE, dan 
ATE. Juga hubungan antara EC terhadap EI dan ATE terhadap EI. Penelitian ini memiliki hasil yaitu EE (entrepreneurial education) memiliki hubungan yang positif dan signifikan terhadap EI (entrepreneurial intention).

Penelitian selanjutnya yaitu yang berjudul "Entrepreneurial education, self-efficacy and intentions in Sub-Saharan Africa". Memiliki tujuan untuk meneliti mediasi dari ESE (Entrepreneurial Self Efficacy) yang dihubungkan dengan EE (entrepreneurial education) dan intensi di Ghana, Africa. Sampel dari penelitian ini adalah pelajar tahun terakhir yang telah selesai kurusus wajib dalam bidang kewirausahaan. Total populasi dari pelajar ini adalah 3,546, sampel yang diambil adalah 400 pelajar menggunakan random sampling. 357 kuesioner dapat digunakan dalam penyebaran sampel tersebut. Hasil dari penelitian ini adalah ESE secara langsung mempengaruhi EI (entrepreneurial intention) dan dapat memediasi EE (entrepreneurial education).

Salah satu penelitian yang berjudul "Who wants to be an entrepreneur? Young adult attitudes to entrepreneurship as a career". Memiliki tujuan untuk mencari tahu hubungan antara sikap pada anak remaja dan pengaruhnya terhadap intensi minat berwirausaha. Sampel dari penelitian ini adalah 117 mahasiswa akhir yang belum lulus yang sedang mempelajari program bisnis. Hasil dari penelitian ini adalah terdapat hubungan yang positif antara sikap yang berhubungan dengan kewirausahaan terhadap intensi minat berwirausaha pada mahasiswa.

\section{Kerangka pemikiran}

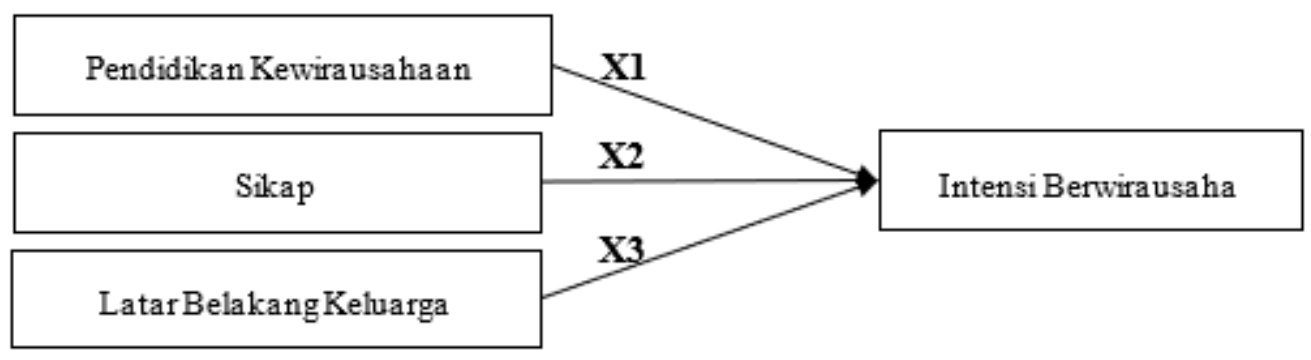

Gambar 1. Kerangka pemikiran

Sumber: Olahan data penulis

Apabila seorang individu sudah merasa matang dan terbekali ilmu yang cukup, individu tersebut akan lebih percaya diri dan lebih termotivasi untuk membuat bisnisnya sendiri, tentunya hal ini akan meningkatkan intensi dalam berwirausaha seorang individu tersebut. Maka dapat dirumuskan hipotesis yaitu:

$\mathrm{H}_{1}$ : Pendidikan kewirausahaan memiliki pengaruh teradap intensi berwirausaha

Kewirausahaan sendiri memiliki makna berusaha menciptakan ide-ide baru dengan cara yang ekstrim dan bersedia mengubah hal-hal yang tidak ternilai atau murah menjadi sesuatu yang bernilai tinggi. Kewirausahaan adalah budaya tak berwujud, kemampuan struktural nonfiskal yang mampu menggerakkan sosok fisik. Seorang wirausahawan unggul perlu memiliki kualitas sikap seperti: Kreatif, Inovatif, Orisinalitas, Berani mengambil risiko, Berorientasi ke depan dan Mengutamakan, Teruji waktu, Rajin, Tidak mudah putus asa, Berjiwa tinggi, disiplin Baja, dan Teguh dalam pendirian Maka dapat dirumuskan hipotesis yaitu:

$\mathrm{H}_{2}$ : Sikap memiliki pengaruh teradap intensi berwirausaha 
Latar belakang keluarga yang mendukung merupakan sumber dukungan yang sangat penting bagi satu individu untuk memulai kegiatan kewirausahaan. Oleh karena itu, hal ini adalah nilai teoritis dan perlu untuk mempertimbangkan lingkungan keluarga seseorang sebagai prediktor kemampuan kewirausahaannya. Maka dapat dirumuskan, yaitu:

$\mathrm{H}_{3}$ : Latar belakang keluarga memiliki pengaruh teradap intensi berwirausaha

\section{METODE PENELITIAN}

Penelitian ini menggunakan penelitian deskriptif karena penelitian ini sudah memuat informasi penelitian sebelumnya dengan variabel yang sama dan hipotesis dalam penelitian ini sudah dapat dirumuskan. Penelitian ini menggunakan pendekatan kuantitatif dengan menggunakan kuisioner sebagai alat pengumpulan data.

\section{Populasi dan Sampel}

Menurut Supranto (2008) menjelaskan bahwa populasi adalah kumpulan dari seluruh elemen sejenis tetapi dapat dibedakan satu sama lain karena karakteristiknya yang berlainan. Populasi yang akan diteliti oleh peneliti di dalam penelitian adalah seluruh mahasiswa Fakultas Ekonomi dan Bisnis Universitas Tarumanagara.

Menurut Sugiyono (2012) sampel adalah bagian dari jumlah dan karakteristik yang dimiliki oleh populasi tersebut. Metode pengambilan sampel dalam penelitian ini adalah metode nonprobability sampling, yaitu teknik pengambilan sampel yang tidak memberi peluang/kesempatan sama bagi setiap unsur atau anggota populasi untuk dipilih menjadi sampel, pengambilan sampel diambil dengan menggunakan teknik purposive sampling adalah teknik penentuan sampel dengan pertimbangan tertentu. Pengambilan sampel berdasarkan "penilaian" (judgement) peneliti mengenai siapa saja yang pantas (memenuhi persyaratan) untuk dijadikan sampel.

Menurut Sugiyono (2012), penelitian dengan analisis multivariate (korelasi atau regresi ganda) maka jumlah anggota sampel yang dapat digunakan adalah minimal 10 kali dari jumlah variabel yang diteliti. Jumlah sampel dalam penelitian adalah sebanyak 4 variabel yang akan diteliti dan dikalikan dengan 10 sehingga mendapatkan hasil sebanyak 40 sampel yang akan diteliti. Menurut penulis, sampel sebanyak 100 sudah memenuhi syarat dalam penelitian yang berada di FEB Universitas Tarumanagara.

\section{Operasionalisasi Variabel dan Instrumen}

Dalam penelitian ini terdapat 4 variabel dan instrumen, yaitu 3 variabel independen dan 1 variabel dependen. Variabel independen yang akan digunakan adalah pendidikan kewirausahaan, sikap dan latar belakang keluarga mahasiswa FEB Universitas Tarumanagara. Sedangkan variabel dependen pada peneliti ini adalah intensi berwirausaha pada mahasiswa FEB Universitas Tarumanagara.

Menurut Mwoma dan Pillay (2016) dukungan pendidikan adalah serangkaian inisiatif yang dirancang untuk meningkatkan pembangunan ekonomi nasional melalui investasi konstan dalam pendidikan berkualitas yang didukung oleh sejumlah guru yang memadai dan alat pembelajaran yang relevan. 
Berikut tabel yang merupakan indikator untuk mengukur variabel budaya inovasi:

Tabel 1. Operasionalisasi variabel Pendidikan Kewirausahaan

Sumber: Yasir et al. (2018)

\begin{tabular}{|c|l|c|c|}
\hline Variabel & \multicolumn{1}{|c|}{ Indikator } & Kode & Skala \\
\hline \multirow{5}{*}{$\begin{array}{c}\text { Pendidikan } \\
\text { Kewirausahaan }\end{array}$} & $\begin{array}{l}\text { Sejauh mana pengetahuan anda tentang dasar- dasar bisnis startup } \\
\text { dan perencanaan bisnis }\end{array}$ & PK1 & Ordinal \\
\cline { 2 - 4 } & Sejauh mana pengetahuan anda tentang keuangan kewirausahaan & PK2 & Ordinal \\
\cline { 2 - 4 } & Sejauh mana pengetahuan anda tentang model bisnis & PK3 & Ordinal \\
\cline { 2 - 5 } & Sejauh mana pengetahuan anda tentang pengembangan gagasan & PK4 & Ordinal \\
\cline { 2 - 5 } & $\begin{array}{l}\text { Sejauh mana pengetahuan anda tentang tanggung jawab seorang } \\
\text { pengusaha }\end{array}$ & PK5 & Ordinal \\
\cline { 2 - 5 } & $\begin{array}{l}\text { Sejauh mana pengetahuan anda tentang proses usaha mulai dari ide } \\
\text { hingga realisasinya }\end{array}$ & PK6 & Ordinal \\
\hline
\end{tabular}

Linan dan Chen (2009) menyebutkan bahwa sikap terhadap kewirausahaan adalah sejauh mana individu memegang penilaian pribadi yang positif atau negatif tentang menjadi seorang pengusaha. Berikut ini merupakan tabel yang merupakan operasionalisasi variabel sikap

Tabel 2. Operasionalisasi variabel Sikap

Sumber: Linan dan Chen (2009)

\begin{tabular}{|c|l|c|c|}
\hline Variabel & \multicolumn{1}{|c|}{ Indikator } & Kode & Skala \\
\hline \multirow{5}{*}{ Sikap } & $\begin{array}{l}\text { Menjadi pengusaha menyiratkan lebih banyak keuntungan daripada } \\
\text { kerugian bagi saya. }\end{array}$ & S1 & Ordinal \\
\cline { 2 - 4 } & Karir sebagai wirausahawan (secara total) menarik bagi saya. & S2 & Ordinal \\
\cline { 2 - 4 } & $\begin{array}{l}\text { Jika saya memiliki kesempatan dan sumber daya, saya ingin sekali memulai } \\
\text { sebuah usaha }\end{array}$ & S3 & Ordinal \\
\cline { 2 - 4 } & Menjadi wirausahawan akan memberikan kepuasan yang besar bagi saya. & S4 & Ordinal \\
\hline
\end{tabular}

Menurut Michel et al. (2011) latar belakang keluarga diartikan sebagai salah satu sumber daya penting yang mendorong semangat individu, sedangkan konflik pekerjaan-keluarga dapat berdampak negatif atau bahkan menghancurkan kinerja pekerjaan dari masing- masing individu. Berikut ini merupakan tabel yang merupakan operasionalisasi variabel pendidikan kewirausahaan.

Tabel 3. Operasionalisasi Variabel Latar Belakang Keluarga

Sumber: Linda et al. (2016)

\begin{tabular}{|c|l|c|c|}
\hline Variabel & \multicolumn{1}{|c|}{ Indikator } & Kode & Skala \\
\hline \multirow{2}{*}{$\begin{array}{c}\text { Latar } \\
\text { Belakang } \\
\text { Keluarga }\end{array}$} & Orang tua / keluarga saya memberi saya modal berupa pinjaman & LK1 & Ordinal \\
\cline { 2 - 4 } & $\begin{array}{l}\text { Orang tua / keluarga saya memberi saya modal berupa ekuitas } \\
\text { Modal yang diberikan oleh orang tua / keluarga saya memiliki kondisi yang }\end{array}$ & LK2 & Ordinal \\
\cline { 2 - 4 } & Ordinal & Ongungkan dan lebih fleksibel \\
\hline
\end{tabular}

\section{HASIL DAN PEMBAHASAN}

\section{Hasil Analisis Data}

Peneliti menggunakan aplikasi smartPLS karena keunggulan yang terdapat dalam software tersebut yang tidak dapat ditemukan dalam software yang lainnya. Model penelitian yang digunakan dalam penelitian ini adalah uji validitas, uji reliabilitas, uji koefisien determinasi $\left(\mathrm{R}^{2}\right)$, uji pengukuran $\mathrm{Q}^{2}$, Uji Goodness of Fit, path coefficients dan uji effect size dilakukan dengan software smartPLS. 
Tabel 4. Hasil Uji Validitas

\begin{tabular}{|c|c|c|c|c|}
\hline & Latar Belakang Keluarga & Intensi Berwirausaha & Pendidikan Kewirausahaan & Sikap \\
\hline LK1 & 0,922 & 0,835 & 0,879 & 0,853 \\
\hline LK2 & 0,907 & 0,880 & 0,875 & 0,926 \\
\hline LK3 & 0,951 & 0,876 & 0,918 & 0,886 \\
\hline IB1 & 0,860 & 0,904 & 0,843 & 0,875 \\
\hline IB2 & 0,862 & 0,890 & 0,898 & 0,838 \\
\hline IB3 & 0,852 & 0,914 & 0,849 & 0,891 \\
\hline IB4 & 0,848 & 0,918 & 0,870 & 0,860 \\
\hline IB5 & 0,853 & 0,939 & 0,890 & 0,870 \\
\hline IB6 & 0,832 & 0,910 & 0,849 & 0,841 \\
\hline PK1 & 0,867 & 0,859 & 0,911 & 0,870 \\
\hline PK2 & 0,905 & 0,843 & 0,920 & 0,880 \\
\hline PK3 & 0,833 & 0,859 & 0,881 & 0,869 \\
\hline PK4 & 0,879 & 0,873 & 0,908 & 0,855 \\
\hline PK5 & 0,877 & 0,887 & 0,912 & 0,883 \\
\hline PK6 & 0,889 & 0,863 & 0,929 & 0,868 \\
\hline S1 & 0,902 & 0,909 & 0,909 & 0,958 \\
\hline S2 & 0,912 & 0,871 & 0,910 & 0,897 \\
\hline S3 & 0,889 & 0,870 & 0,860 & 0,928 \\
\hline S4 & 0,893 & 0,891 & 0,906 & 0,964 \\
\hline
\end{tabular}

Data dapat dikatakan valid apabila hasil nilai uji validitas yang diukur dengan menggunakan loading factors memiliki nilai lebih dari 0,5 (Yamin \& Kurniawan, 2009). Nilai hasil uji loading factors pada penelitian ini lebih dari 0,5 sehingga penelitian ini dapat dikatakan valid. Adapun hasil uji validitas pada uji discriminant validity apabila melebihi dari nilai 0,5 maka dapat dikatakan valid, dari pengujian validitas diatas terbukti bahwa semua nilai dari masing- masing indikator pada tabel discriminant validity melebihi 0,5 yang dapat dinyatakan bahwa semua variabel atau indikator diatas valid. Uji reliabilitas pada penelitian ini menggunakan metode yaitu pengujian reliabilitas dalam PLS menggunakan Composite Reliability. Penelitian dikatakan reliabel apabila nilai Cronbach's Alpha lebih dari 0,6 dan apabila kurang dari 0,6 maka tidak reliabel.

Nilai Cronbach's Alpha dan Composite Reliability pada penelitian ini memiliki seluruh nilai konstruk yang lebih dari 0,60 , sehingga nilai konstruk tersebut dapat dikatakan reliabel. Nilai batas uji AVE yang direkomendasikan adalah melebihi 0,5 sehingga suatu penelitian dapat dikatakan valid. Dapat dijelaskan bahwa AVE dalam penelitian ini telah memenuhi kriteria dan penelitian ini dapat dinyatakan valid.

\section{Hasil Uji R-Square dan Q-Square}

Semakin tinggi nilai $R$-Square dapat dikatakan bahwa semakin baik juga model prediksi dipengaruhi model penelitian. Nilai $R$-Square dalam penelitian ini adalah 0,915. dapat menjelaskan bahwa variabel pendidikan kewirausahaan, sikap dan latar belakang keluarga memiliki pengaruh yang kuat terhadap intensi berwirausaha yaitu sebesar 91,5\%. Sedangkan sisanya yaitu $8,5 \%$ dipengaruhi oleh variabel lain yang tidak terdapat dalam penelitian ini seperti efikasi diri, orientasi kewirausahaan, pengaruh sosial dan variabel lainnya. Berdasarkan hasil yang didapat dari olah data pada penelitian ini, nilai $Q$-square dapat dijelaskan bahwa bahwa variabel pendidikan kewirausahaan, sikap dan latar belakang keluarga memiliki pengaruh yang kuat terhadap intensi berwirausaha yaitu sebesar 0,744 . 


\section{Hasil Uji Goodness of Fit (GoF)}

Dalam melakukan uji GoF, peneliti harus mengetahui terlebih dahulu atau menghitung nilai AVE dalam penelitian tersebut. Nilai AVE (Average variance extracted) pada penelitian ini adalah 0,849 sehingga nilai GoF pada penelitian ini adalah 0,881 , hal ini dapat dikatakan bahwa nilai atau tingkat kelayakan pada model penelitian ini dinyatakan besar.

\section{Hasil Uji Path Coefficients}

Berdasarkan nilai uji hipotesis dapat dijelaskan, maka dapat diperoleh persamaan dalam penelitian ini yaitu Intensi Berwirausaha $=0,514$ Pendidikan Kewirausahaan $+0,411$ Sikap + 0,044 Latar Belakang Keluarga. Berdasarkan persamaan tersebut dapat dilihat bahwa variabel independen (X1) yaitu pendidikan kewirausahaan memiliki hubungan positif terhadap variabel dependen $Y$ yaitu intensi berwirausaha, variabel independen (X2) yaitu sikap memiliki hubungan positif terhadap variabel dependen $\mathrm{Y}$ yaitu intensi berwirausaha, dan variabel independen (X3) yaitu latar belakang keluarga memiliki hubungan positif terhadap variabel dependen $\mathrm{Y}$ yaitu intensi berwirausaha.

\section{Diskusi}

Sebelumnya hasil pengujian yang telah dilakukan pada variabel pendidikan kewirausahaan terhadap intensi berwirausaha memiliki pengaruh positif dan signfikan terhadap intensi berwirausaha pada mahasiswa FEB Universitas Tarumanagara. Hal ini sejalan dengan penelitian yang telah dilakukan oleh Wilson et al. (2007) yang menyebutkan bahwa ada hubungan yang positif dan signifikan antara pendidikan kewirausahaan terhadap intensi berwirausaha pada mahasiswa. Menurutnya, dukungan pendidikan merupakan pendidikan kewirausahaan yang dapat meningkatkan tingkat efikasi diri dan membantu siswa dalam mengekspresikan niat lebih lanjut untuk memulai usaha mereka sendiri, meningkatkan keinginan mereka dan menginspirasi mereka untuk mengambil tantangan baru.

Sebelumnya hasil pengujian yang telah dilakukan pada variabel sikap terhadap intensi berwirausaha memiliki pengaruh positif dan signfikan terhadap intensi berwirausaha pada mahasiswa FEB Universitas Tarumanagara Penelitian ini sejalan dengan penelitian yang telah dilakukan oleh Indarti, (2020) yang menyatakan bahwa sikap memiliki pengaruh signifikan terhadap intensi berwirausaha dan berpengaruh positif. Keyakinan untuk meraih sukses harus diimbangi sikap yang selalu ingin tahu, dengan sikap ini, individu akan memiliki minat untuk belajar dan meningkatkan diri. Tanpa sikap ini, keyakinan hanya akan tetap sebagai keyakinan fiksi. Oleh karena itu, harus dibangun sikap yang kuat agar kita dapat memberanikan diri untuk memulai suatu usaha.

Sebelumnya hasil pengujian yang telah dilakukan pada variabel latar belakang keluarga terhadap intensi berwirausaha memiliki pengaruh positif namun tidak signfikan terhadap intensi berwirausaha pada mahasiswa FEB Universitas Tarumanagara Penelitian ini bertolak belakang dengan penelitian yang dibuat oleh Weichun et al. (2020). Hubungan yang baik antara orang tua sendiri yang tertanam dalam keluarga yang sehat dan harmonis juga dapat memberikan sumber daya yang melimpah kepada anak-anak mereka untuk menghadapi berbagai tantangan dan mengatasi hambatan, sehingga seorang individu dapat memiliki dukungan cukup berwirausaha (Weichun et al., 2020).

Menurut Michel et al. (2011) juga menyebutkan bahwa latar belakang keluarga merupakan salah satu sumber daya penting yang mendorong semangat individu, sedangkan konflik pekerjaankeluarga dapat berdampak negatif atau bahkan menghancurkan kinerja pekerjaan dari masing- 
masing individu. Hasil penelitian ini bertolak belakang karena mahasiswa cenderung kurang mendapatkan dukungan untuk membuat suatu wirausaha dari lingkungan keluarganya. Menurut beberapa responden, keluarga memiliki beberapa hambatan untuk mendukung mereka berwirausaha, seperti kurangnya sumber dana/modal, mayoritas responden juga menyebutkan bahwa keluarga kurang mendukung secara moral atau perhatian dan lebih bersikap pesimis.

Pada hasil pengujan yang telah dilakukan, indikator PK3 memiliki nilai yang rendah diantara indikator lainnya, pernyataan indikator tersebut berisi "Sejauh mana pengetahuan anda tentang model bisnis". Untuk itu peneliti menyarankan mahasiswa untuk lebih sadar akan pentingnya pengetahuan tentang model bisnis. Mahasiswa dapat lebih banyak membaca dari berbagai sumber baik buku, internet, dan jurnal, sehingga mahasiswa bisa mendapatkan sumber ilmu pengetahuan akan model bisnis yang lebih luas.

\section{KESIMPULAN DAN SARAN}

Pendidikan kewirausahaan terhadap intensi berwirausaha memiliki pengaruh positif dan signfikan terhadap intensi berwirausaha pada mahasiswa FEB Universitas Tarumanagara. Responden merasa mereka memerlukan pendidikan kewirausahaan sebagai sarana mendapatkan sumber pengetahuan dan arahan untuk memunculkan intensi berwirausaha.

Sikap terhadap intensi berwirausaha memiliki pengaruh positif dan signfikan terhadap intensi berwirausaha pada mahasiswa FEB Universitas Tarumanagara. Responden menyadari akan sikap atau perilaku yang pantas untuk menjadi seorang wirausaha, seperti contohnya adalah mengasah rasa ingin tahu dari responden.

Latar belakang keluarga terhadap intensi berwirausaha memiliki pengaruh positif namun tidak signfikan terhadap intensi berwirausaha pada mahasiswa FEB Universitas Tarumanagara. Responden menyadari dan mengerti arti dari latar belakang keluarga sebagai modal awal untuk memulai suatu usaha, selain itu responden juga memerlukan dukungan dalam bentuk moral sehingga akan berdampak baik pada intensi berwirausaha responden. Pada sisi konflik pekerjaan dengan keluarga dapat berdampak negatif atau bahkan menghancurkan kinerja pekerjaan dari masing- masing individu.

\section{REFERENSI}

Baughn, C., Chua, B., \& Neupert, K. (2006). The normative context for women's participation in entrepreneruship: a multicountry study. Entrepreneurship Theory and Practice, Vol. 30 No. 5, pp. 687-708.

Chairy. (2011). Pengaruh Karakteristik Entrepreneurial, Jenis Etnis, Jenis Kelamin Dan Profesi Orang Tua Terhadap Intensi Berwirausaha MahasiswavProsiding Dalam Rangkaian Seminar Internasional. Journal of Towards Excellent Small Business.

Cruz, L. D., Suprapti, N. W., \& Yasa, N. K. (2015). Aplikasi Theory of Planned Behavior Dalam Membangkitkan Niat Berwirausaha Bagi Mahasiswa Fakultas Ekonomi Unpaz Dili Timor Leste. E-Jurnal Ekonomi dan Bisnis Universitas Udayana, 4(12), pp. 895-920.

Endah, \& Eny. (2013). Pengaruh Kepribadian Dan Lingkungan Terhadap Intensi Berwirausaha Pada Usia Dewasa Awal. Buletin Ekonomi, Vol. 11, No. 1, hal 1-86.

Gibb, A. (2005). Towards the Entrepreneurial University: Entrepreneurship Education as a Lever for Change. National Council for Graduate Entrepreneurship.

Hannon, P. (2006). Teaching pigeons to dance: sense and meaning in entrepreneurship education. Education p Training, Vol. 48 No. 5, pp. 296-308. 
Honig, B., \& Davidsson, P. (2000). The role of social and human capital among nascent entrepreneurs. Academy of Management Proceedings, Vol. 2000, August, pp. B1-B6.

Indarti, S. (2020). The effects of education and training, management supervision on development of entrepreneurship attitude and growth of small micro and enterprise. Attitude and growth of small and micro enterprise, 1 - 60.

Linan, F., \& Chen, Y. (2009). Development and Cross-Cultural Application of a Specific Instrument to Measure Entrepreneurial Intentions. Entrepreneurship Theory and Practice, 33(3), 593-617.

Linda, F., Tatiana, M., Galina, S., \& Tatyana, T. (2016). The impact of family support on young entrepreneurs' start-up activities. Journal of Business Venturing, 428-448.

Michel, J., Kotrba, L., Mitchelson, J., Clark, M., \& Baltes, B. (2011). Antecedents of work family conflict: a meta-analytic review. Journal of Organizational Behavior, Vol. 32 No. 5, pp. 689-725.

Mwoma, T., \& Pillay, J. (2016). Educational support for orphans and vulnerable children in primary schools: challenges and interventions. Issues in Educational Research, Vol. 26 No. 1, pp. 82-97.

Sivarajah, K., \& Achchuthan, S. (2013). Entrepreneurial Intention among undergraduates: Review of literature. European Journal of Business and Management, Vol. 5, no. 5, pp. $172-186$.

Sugiyono. (2012). Metode Peneitian Pendidikan (Pendekatan Kuantitatif, Kualitatif dan R\&D), Bandung: Alfabeta.

Sukidjo. (2005). Peran Kewirausahaan Dalam Mengatasi Pengangguran Di Indonesia. Jurnal Economia, 1(1), 17-28.

Supranto. (2008). Statistik Teori dan Aplikasi. Jakarta: Penerbit Erlangga.

Susita, D. (2013). Pengaruh sikap kewirausahaan, kepribadian, kepuasan kerja, dan komitmen, terhadap efektivitas kerja karyawan kementrian perindustrian. Jurnal Kewirausahaan.

Weichun, Z., Jinyi, Z., Wai, K., \& Steve, W. (2020). How harmonious family encourages individuals to enter enrepreneurship: a view from conservation of resource theory. Harmonious family encourages individuals, 333 - 339.

Wilson, F., Kickul, J., \& Marlino, D. (2007). Gender, entrepreneurial self-efficacy, and entrepreneurial career intentions: implications for entrepreneurship education. Entrepreneurship Theory and Practice, Vol. 31 No. 3, pp. 387-406.

Yamin, S., \& Kurniawan, H. (2009). Structural Equation Modeling dengan Lisrel - PLS. Jakarta : Penerbit Salemba.

Yasir. (2018). Entrepreneurial self-efficacy and intention: do entrepreneurial creativity and education matter? International Journal of Entrepreneurial Behavior \& Research.

Zachary, R. (2011). The importance of the family system in family business. Journal of Family Business Management, Vol. 1 No. 1, pp. 26-36. 